\title{
Two wins for environmentalists in Australian wilderness battle
}

\section{Sydney}

IN the past week Australia's federal Labor government has won two battles in its campaign to conserve the cream of the continent's wilderness areas in conservatively governed states. In the Northern Territory, a court gave the federal government permission to proceed with the nomination of the $6,929 \mathrm{~km}^{2}$ of Kakadu National Park Stage 2 for inscription on the UNESCO World Heritage list. And in Tasmania, a court upheld the federal governments right to prevent logging or road construction in an area also being considered for World Heritage listing over the state government's objection.

In the Kakadu National Park, a mining company which felt that its interests had not been properly taken into account had sought to block the World Heritage listing. The company holds exploration lcases in the area thought to contain uranium as well as gold, platinum and basic metal deposits. World Heritage status would forbid both mining and exploration (Nature 326,434; 1987).
The Tasmanian area is virgin cold-temperature rain forest. It is the habitat of the world's tallest flowering plant, the Swamp gum, which can grow up to $99 \mathrm{~m}$ high.

The next target for listing is likely to be $9,300 \mathrm{~km}^{2}$ of tropical rainforest along the north coast of Queensland near the town of Cairns. According to the federal minister for the environment, Senator Graham Richardson, the north Queensland rainforest contains the highest concentration of primitive flowering plants in the world and holds important clues to the origin, evolution and migration of flowering plants. Australian conservationists maintain that even though the size of the north Queensland rainforest is small by world standards, it is the only tropical rainforest inside a developed country.

But the right-wing premier of Queensland, Sir Johannes Bjelke-Petersen, sees the World Heritage listing as a takeover attempt by the federal government and has vowed to do everything within his government's power to prevent it

Charles Morgan

\section{First steps in ozone protection agreed}

\section{London}

A IISTORic agreement to protect the Earth's ozone layer is due to be signed this week in Montreal, the culmination of months of negotiations over the specific timing and severity of regulations to limit the man-made chemicals chlorofluorocarbons (CFCs) and halons.

During last week's tough negotiating session on several contentious issues involved in the protocol, it looked at times as if the protocol might break down completely, but always it was steered back on track. However, even as ministers and government representatives from some $\mathbf{3 5}$ countries arrived for the final session, some outstanding issues remained.

The final document looked set to provide a 50 per cent cutback in the consumption of CFCs 11, 12113,114 and 115 by the beginning of 1999, following a freeze in 1990 and a 20 per cent cut-back in 1994. Halons 1211 and 1301 , widely used as fire extinguishants, will be frozen at 1986 levels by 1993 .

Research results expected in a matter of weeks on both Antarctic and global ozone depletion should help shed some light on the question of whether the new regulations go far enough, and the United Nations Environment Programme director Dr Mostafa Tolba has reserved the right to call an emergency meeting if necessary. No one was willing to postpone the protocol signing, however, for fear of upsetting its delicate momentum.

Insistence by the United States, Canada and Nordic countries on the need for a 95 per cent reduction in CFCs is thought to be largely responsible for the shape of the final agreement with its 50 per cent cutback; considering the position of some countries, including Britain, at the start of negotiations last December, a mere freeze on CFC production was another possible outcome.

Many hours of intense discussions in Montreal over the issue of CFC use by developing countries resulted in a compromise allowing a ten-year grace period during which these low-consuming countries would be allowed to reach a ceiling of $0.3 \mathrm{~kg}$ per person of CFCs (compared with an estimated $0.8 \mathrm{~kg}$ in developed countries).

In a compromise between the United States and the European Community countries, CFC limits will apply to consumption, rather than production, which would still allow exports of the chemicals.

The actual numbers included in the protocol specifying percentages are recognized as politically rather than scientifically based but the agreement is being hailed as an important first step in ozone protection. It remains to be seen whether results from the latest Antarctic expedition and studies by the US National Aeronautics and Space Administration will demonstrate a need for further restrictions.

Kathy Johnston
Swedish view of US science policy tangles

\section{Washington}

DR Frank Press, president of the US National Academy of Sciences, last week took on the daunting task of describing US science policy to the Swedish Prime Minister, Ingvar Carlsson, during his state visit to Washington. After describing scientific enterprise in the United States as "decentralized, some would say disorganized, and yet successful", Press led a lively if eclectic 100-minute discussion staged at Carlsson's request.

Not wanting to shoulder the burden alone, Press asked James Wyngaarden, director of the National Institutes of Heaith. and Erich Bloch, director of the National Science Foundation, to explain the role of civilian agencies in supporting science. Representatives of defence research

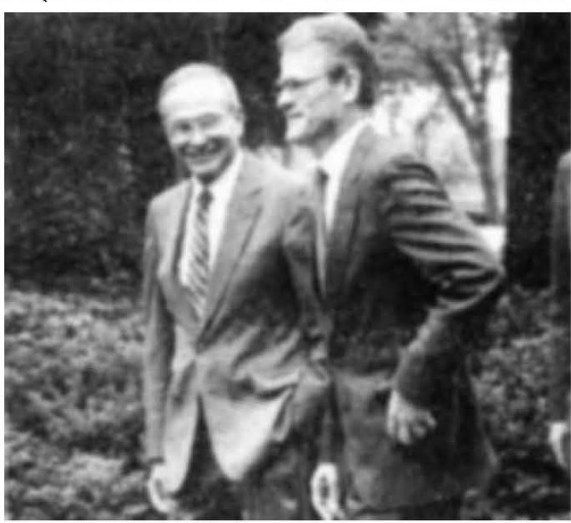

Press (left) and Carlsson - future possibilities.

funding agencies were notably absent.

Sam Thier, president of the Institute of Medicine, and Robert White, president of the National Institute of Engineering, described how independent scientific organizations could advise government. Carlsson asked if their advice was heeded, but White dodged the question, explaining that government agencies had usually asked for the advice in the first place.

One immediate issue touched on and probed more deeply at a later meeting without the prime minister was data transfer. Sweden will house the secretariat for the International Geosphere/ Biosphere Programme (IGBP), making it the focal point for a huge volume of data. Earth observation satellites from several countries will produce a steady deluge of telemetry that will need to be collected and distributed to make IGBP a success.

Carlsson told his hosts that he met regularly with members of the Swedish scientific community, often once a month. Scientists present possibilities, said Carlson, whereas most of a prime minister's job consists of coping with problems.

Joseph Palca 